\title{
Clinical Failure and Emergence of Resistance during Third Generation Cephalosporin Therapy for Enterobacter spp. Infection: Is the Risk Overestimated? A Prospective Multicentric Study
}

\author{
Benoît Pilmis 1,2,*, Thibaud Delerue ${ }^{3,4}$, Anna Belkacem ${ }^{5}$, Pauline Caraux-Paz ${ }^{5}$, Solen Kernéis ${ }^{6,7}$, \\ Sophie Alviset ${ }^{6,7}$, Etienne Canoui ${ }^{6,7}$, Assaf Mizrahi ${ }^{2,8}$, Alexandre Bleibtreu ${ }^{9} \mathbb{D}$, Matthieu Lafaurie ${ }^{10}$, \\ Etienne Carbonnelle ${ }^{4,11}$ and Jean-Ralph Zahar ${ }^{3,4}$
}

check for

updates

Citation: Pilmis, B.; Delerue, T.; Belkacem, A.; Caraux-Paz, P.; Kernéis, S.; Alviset, S.; Canoui, E.; Mizrahi, A.; Bleibtreu, A.; Lafaurie, M.; et al. Clinical Failure and Emergence of Resistance during Third Generation Cephalosporin Therapy for Enterobacter spp. Infection: Is the Risk Overestimated? A Prospective Multicentric Study. Hygiene 2021, 1, 69-79. https://doi.org/10.3390/ hygiene1020007

Received: 27 April 2021

Accepted: 24 June 2021

Published: 20 August 2021

Publisher's Note: MDPI stays neutral with regard to jurisdictional claims in published maps and institutional affiliations.

Copyright: (c) 2021 by the authors. Licensee MDPI, Basel, Switzerland. This article is an open access article distributed under the terms and conditions of the Creative Commons Attribution (CC BY) license (https:// creativecommons.org/licenses/by/ $4.0 /)$.
Equipe Mobile de Microbiologie Clinique, Groupe Hospitalier Paris Saint-Joseph, 75014 Paris, France

2 EA4043 Unité Bactéries Pathogènes et Santé, Université Paris-Sud Saclay, 92290 Chatenay-Malabry, France; amizrahi@hpsj.fr

3 Laboratoire de Microbiologie, Unité de Prévention et de Lutte Contre les Infections Nosocomiales, GH Paris Seine Saint-Denis, APHP, 93022 Bobigny, France; thibaut.delerue@aphp.fr (T.D.); jeanralph.zahar@aphp.fr (J.-R.Z.)

4 INSERM, IAME, UMR 1137, Université de Paris, 75018 Paris, France; etienne.carbonelle@aphp.fr

5 Service de Maladies Infectieuses et Tropicales, 94190 Villeneuve Saint Georges, France; anna.belkacem@chiv.fr (A.B.); pauline.caraux-paz@chiv.fr (P.C.-P.)

6 Assistance Publique Hôpitaux de Paris, Hôpitaux Universitaires Paris Centre-Site Cochin, Antimicrobial Stewardship Team, 75014 Paris, France; solen.kerneis@aphp.fr (S.K.); sophie.alviset@aphp.fr (S.A.); etienne.canoui@aphp.fr (E.C.)

7 Faculté de Médecine, Sorbonne Paris Cité, Université de Paris, 75006 Paris, France

8 Service de Microbiologie Clinique, Groupe Hospitalier Paris Saint-Joseph, 75014 Paris, France

9 Service des Maladies Infectieuses et Tropicales, Pitié Salpêtrière-Charles Foix, 75013 Paris, France; alexandre.bleibtreu@aphp.fr

10 Unité Fonctionnelle Infectiologie, Hôpital St. Louis, 75010 Paris, France; matthieu.lafaurie@aphp.fr

11 Laboratoire de Microbiologie, GH Paris Seine Saint-Denis, APHP, 93022 Bobigny, France

* Correspondence: bpilmis@ghpsj.fr; Tel.: +33-1-44-12-78-20

Abstract: Background: Clinical and microbiological guidelines recommend treating infections caused by Enterobacter spp. with cefepime or carbapenems. The main objective of this study was to assess the risk of clinical failure with third generation cephalosporin (3GC) therapy compared to other $\beta$-lactams for infections caused by Enterobacter spp. Our secondary objective was to evaluate the risk of emergence of resistance during therapy. Methods: We conducted a prospective observational study in seven French hospitals over an 18-month period including all patients with a pulmonary and/or bloodstream infection due to Enterobacter spp. susceptible to 3GC. Results: Seventy-four patients were included in our study. Among them, 26 (35\%) received a 3GC as a first-line treatment, and clinical improvements were observed for $13 / 21$ (62\%) of them. Four (5\%) cases of emergence of 3GC resistance were observed during therapy including one in the 3GC group. 3GC therapy can be safely used as first-line therapy especially for non-severe patients suffering from pulmonary or bloodstream infections due to Enterobacter spp. Conclusions: Emergence of 3GC resistance remains a rare event, and there is a lack of evidence of the benefit of last-line antibiotics therapies.

Keywords: AmpC producing Enterobacteriaceae; cefepime; piperacilline/tazobactam; third generation cephalosporin

\section{Introduction}

The Enterobacteriaceae family is a major cause of community and healthcare related infections. Several species as Enterobacter spp., Serratia marcescens, Citrobacter freundii, Providencia spp. and Morganella morganii possess natural chromosomic AmpC $\beta$-lactamase 
that hydrolyze benzylpenicillin, amoxicillin, ampicillin and cefazolin [1]. Other $\beta$-lactamins such as third generation cephalosporins (3GCs) may also be affected in the case of an overproduction of these enzymes.

Due to a high risk of mutant selection, several recommendations [1,2] suggest avoiding use of 3GC to treat AmpC producing Enterobacteriaceae (AE). Previous studies reported a high risk of resistance reaching $19 \%$ in patients with infections related to Enterobacter spp. during 3GC antibiotic therapy [3,4]. Nevertheless, these studies suffer from methodological bias, as authors did not take into account several confounding factors involved in the selection of resistant strains such as the PK/PD parameters (minimal inhibitory concentration, MIC; source of infection; initial dosage and modalities of administration) and did not discriminate the risk of emergence of resistance according to species. Hence, a recent prospective study underlined a lower risk of resistance during 3GC therapy and observed different risks according to the involved species and site of infection. Indeed, among the different species possessing AmpC $\beta$-lactamase, Enterobacter spp. seems to have the highest risk of emergence of resistance under treatment compared to Morganella morganii and Serratia marcescens. Furthermore, source of infection seems to play a role in undrained biliary tract infection as a factor associated with the emergence of resistance [5].

The 3GCs remain the first-line recommended antibiotics as probabilistic treatment for infections related to Enterobacteriaceae, despite the fact that Enterobacter spp. are more and more frequently isolated, being ranked fourth and sixth among the bacteria isolated from patients hospitalized with pneumonia in the USA and Europe, respectively [6]. Despite antimicrobial guidelines discouraging the use of 3GC (EUCAST) when Enterobacter spp. is secondarily identified, the decision to switch the 3GC initially used to another $\beta$-lactamin such as cefepime, piperacillin, piperacillin-tazobactam or carbapenem varies according to infectious disease practitioners. Indeed, the link between therapeutic failure and the use of 3GC remains uncertain except for urinary tract infection, for which 3GC can be used safely because adequate antibiotic penetration can be achieved $[5,7,8]$. For all other sites of infection, most studies were retrospective and only partially investigated the outcome of patients treated with $3 \mathrm{GC}$ for AE related infection.

We therefore prospectively assessed the risk of clinical failure with 3GC therapy compared to other $\beta$-lactams in two deep infections: pulmonary and bloodstream infections due to Enterobacter spp. Our secondary objective was to evaluate the risk of emergence of resistance during therapy.

\section{Materials and Methods}

\subsection{Design and Study Population}

We conducted a prospective observational study in 7 French hospitals over an 18-month period (from 1 January 2017 to 1 June 2018). All patients with a pulmonary or bloodstream infection, as defined below, due to Enterobacter spp. susceptible to 3GC were included and monitored until the time of discharge. All data were prospectively and anonymously collected.

\subsection{Characteristics of Patients}

At inclusion the following data were recorded: demographics characteristics, underlying disease (chronic cardiac failure, chronic pulmonary disease, chronic renal failure with renal clearance, diabetes mellitus, hematologic malignancies, solid cancer, inflammatory disease), immunosuppressive treatment (immunosuppressive drugs including tumor necrosis factor (TNF) antagonists, corticosteroid and chemotherapy drugs), Charlson Comorbidity Index [9] and prior use of antibiotics (during the last 3 months).

\subsection{Clinical and Physiological Parameters}

At time of infection, the following data were recorded: initial severity of infection measured with Pitt score (non-ICU patients) and SOFA score (ICU patients), source of infection, presence of central venous catheter (CVC), inflammatory parameters such as procalcitonin (PCT), C-reactive protein (CRP), total leukocyte count, uremia and creatininemia when available. 
At $72 \mathrm{~h}$ after the first dose of antibiotic treatment, clinical data and inflammatory parameters were recorded as: body temperature, heart and respiratory rate, PCT, CRP and persistence of the organism at the site of infection determined as positivity of microbiological samples. Emergence of resistance was defined as a positive blood culture or a positive sample at the same site of infection to Enterobacter spp. overproducing AmpC during treatment. All antibiotics prescription data, dosages and modalities of administration were collected from the beginning of the infection to the discharge.

\subsection{Definition}

Pulmonary infection was considered when:

- Impairment of lung function and infiltration in the chest X-ray film was observed;

- $\quad$ Fever $\geq 38.3^{\circ} \mathrm{C}$ or leukocytosis $\geq 10,000 / \mu \mathrm{L}$ was observed.

Pulmonary infection was related to Enterobacter spp. if isolated at a concentration of:

- $\quad \geq 10^{4} \mathrm{CFU} / \mathrm{mL}$ from bronchoalveolar lavage (BAL) sample;

- $\quad \geq 10^{3} \mathrm{CFU} / \mathrm{mL}$ from protected specimen brushing;

- $\quad \geq 10^{5} \mathrm{CFU} / \mathrm{mL}$ from tracheal aspiration.

Bloodstream infection related to Enterobacter spp. was defined as a positive blood culture with sepsis signs according to Bone's criteria [10].

The primary source of bacteremia was determined according to CDC criteria [11]. Otherwise, it was defined as primary bacteremia with undetermined source of infection. Initial time of infection was defined as the day of the first sample collection date positive to Enterobacter spp., which corresponds to the day of first clinical symptoms for hospitalized patients. Clinical failure was defined as the persistence of clinical symptoms $72 \mathrm{~h}$ after the antibiotic treatment had been started and persistence of abnormal heart and respiratory rate. Biological failure was defined as PCT or CRP level $>$ half of the initial dosage $72 \mathrm{~h}$ after antibiotic treatment. Renal clearance was calculated using the Cockcroft and Gault formula. Emergence of 3GC resistance was defined as a positive culture to Enterobacter spp. overproducing AmpC $\beta$-lactamase at the site of infection. Mortality was defined as the 30-day mortality after the infection.

First-line treatment was defined as first antibiotic therapy received to treat the infection. Adequate therapy was defined as a standard parenteral dose of an antimicrobial to which the Enterobacter strain was susceptible in vitro or a standard oral dose of an antimicrobial with good bioavailability to which the Enterobacter strain was susceptible in vitro such as fluoroquinolones and sulfamethoxazole-trimethoprim. Definitive treatment was defined as the last antibiotic treatment received.

\subsection{Microbiological Methods}

Enterobacter spp. were identified on bacterial culture by matrix-assisted laser desorption/ionization time-of-flight mass spectrometry (MALDI-TOF MS, Bruker Daltonics, Billerica, MA, USA). Susceptibility testing was performed according to the European Committee on Antimicrobial Susceptibility Testing (EUCAST) guidelines [12]. When the isolate was resistant to any of the 3GCs tested (cefotaxime, ceftriaxone and ceftazidime), it was regarded as resistant to all broad spectrum cephalosporins. ESBL producing Enterobacter sp. were excluded. 3GC resistant Enterobacter spp. by AmpC $\beta$-lactamase overproduction was confirmed following EUCAST guidelines [12].

\subsection{Statistics}

The descriptive statistics are based on means ( \pm standard deviation) or medians (minimum-maximum) depending on the distribution of quantitative variables. The qualitative variables are described in terms of number $(\%)$. Univariate comparisons used standard statistical tests after verifying the distribution of variables with a degree of significance of $5 \% ; 95 \%$ confidence intervals are provided for each estimate. Calculations were performed using the R and SAS software. 


\section{Results}

\subsection{Study Population}

During the study period, 79 cases were reported; among them, five $(6 \%)$ were excluded because of lack of sufficient data, resulting in a final total of 74 infections related to Enterobacter spp. susceptible to 3GC (Figure 1).

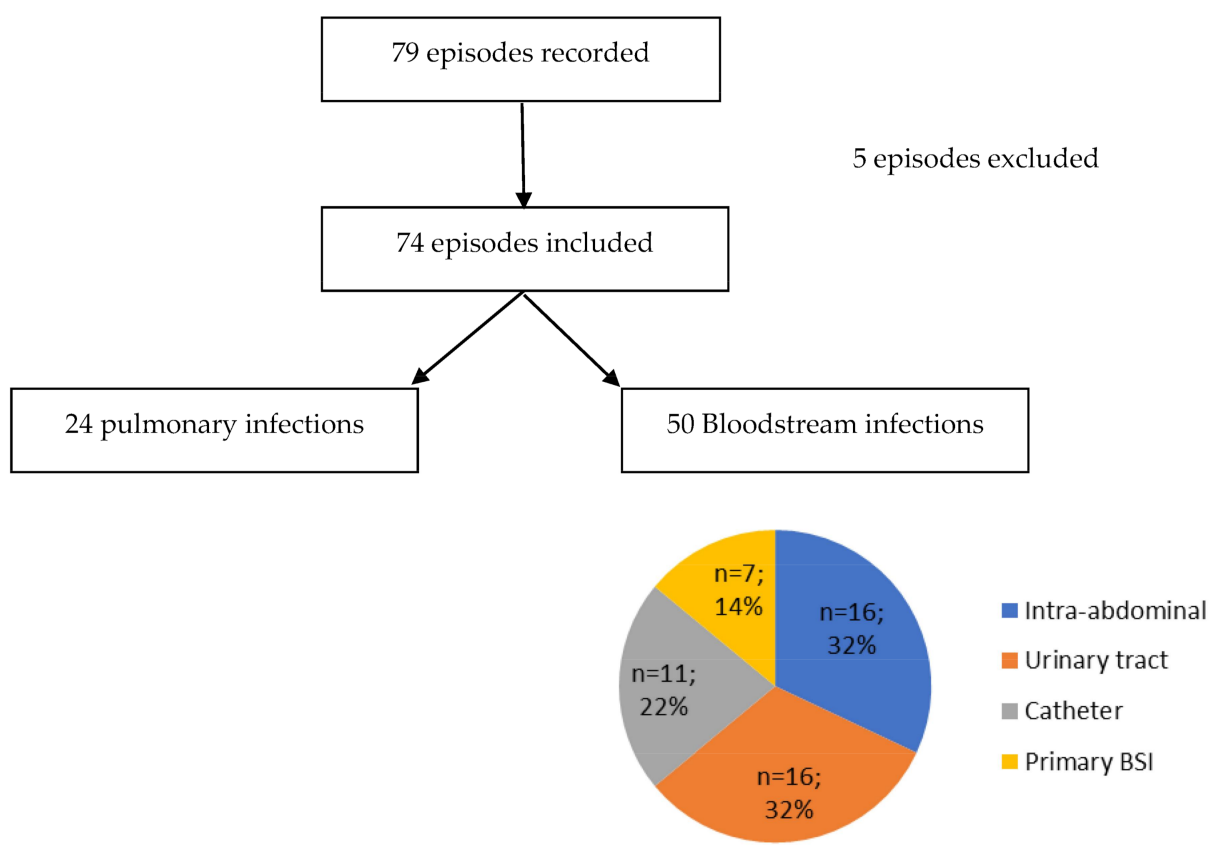

Source of Bloodstream Infection (BSI)

Figure 1. Description of episodes included.

\subsection{Characteristics of Population}

Underlying disease and infection characteristics of studied patients are presented in Table 1. Seventy-two percent of patients were men. The age ranged from 21 to 89 years (median, 69 years). The most common underlying disease was diabetes mellitus ( $\mathrm{n}=19$, $24.3 \%)$, chronic cardiac disease $(\mathrm{n}=14,18.9 \%)$ and chronic respiratory disease $(\mathrm{n}=14$, $18.9 \%)$. We recorded $50(67.6 \%)$ bloodstream infections and $24(32.4 \%)$ pulmonary infections. Among bloodstream infections, the most frequent sources of infection were intra-abdominal infections (IAIs) $(n=16,32 \%)$ and urinary tract infections (UTIs) $(n=16,32 \%)$, whereas primary bacteremia was observed in seven cases (14\%) (Figure 1). We recorded $22(29.7 \%)$ community related infections and $52(70.3 \%)$ hospital acquired infections. Half of patients $(\mathrm{n}=39,52.7 \%)$ received previous antibiotic therapy in the last three months. No patient had a fungal or viral co-infection such as influenza.

\subsection{Antibiotic Therapy}

All patients $(n=74,100 \%)$ patients received a $\beta$-lactam as first-line therapy and were considered as adequate in all cases according to antibiotic susceptibility tests. Descriptions of antibiotics therapies are listed Table 2. 
Table 1. Characteristics of population.

\begin{tabular}{|c|c|}
\hline & No. (\%) of Patients \\
\hline Total & $74(100)$ \\
\hline \multicolumn{2}{|l|}{ Infection } \\
\hline BSI & $50(67.6)$ \\
\hline Respiratory tract infection without BSI & $24(32.4)$ \\
\hline \multicolumn{2}{|l|}{ Source of BSI } \\
\hline Intra-abdominal & $16(32)$ \\
\hline Urinary tract & $16(32)$ \\
\hline Catheter & $11(22)$ \\
\hline Primary BSI & $7(14)$ \\
\hline Respiratory tract & $0(0)$ \\
\hline Male & $53(71.6)$ \\
\hline Age (median, [IQR]) & 69 [60.1-77.9] \\
\hline \multicolumn{2}{|l|}{ Ward at the time of infection } \\
\hline Medicine & $36(48.6)$ \\
\hline Intensive Care Unit & $31(41.9)$ \\
\hline Surgery & $6(8.1$ \\
\hline Home & $1(1.4)$ \\
\hline Antibiotic therapy in the last 3 months & $39(52.7)$ \\
\hline \multicolumn{2}{|l|}{ Underlying disease } \\
\hline Diabetes mellitus & $18(24.3)$ \\
\hline Chronic cardiac disease & $14(18.9)$ \\
\hline Chronic Respiratory disease & $14(18.9)$ \\
\hline Renal insufficiency & $10(13.5)$ \\
\hline Neutropenia $\left(\mathrm{PNN}<500 / \mathrm{mm}^{3}\right)$ & $0(0)$ \\
\hline Immunosuppressive treatment & $9(12.2)$ \\
\hline Corticosteroid use & $2(2.7)$ \\
\hline Hematologic malignancies & $2(2.7)$ \\
\hline Solid cancer & $32(43.2)$ \\
\hline Inflammatory disease & $0(0)$ \\
\hline $\mathrm{HIV}<200 \mathrm{CD} 4 / \mathrm{mm}^{3}$ & $0(0)$ \\
\hline Charlson score (median, [IQR]) & $2[1-4.75]$ \\
\hline \multicolumn{2}{|l|}{ Severity of infection } \\
\hline SOFA score (mean) & $5.9 \pm 2.5$ \\
\hline Pitt score (mean) & $2.5 \pm 1.2$ \\
\hline \multicolumn{2}{|l|}{ Biology (median, [IQR]) } \\
\hline PCT $(\mu \mathrm{g} / \mathrm{L})$ & $2[0.89-5.5]$ \\
\hline $\mathrm{CRP}(\mathrm{mg} / \mathrm{L})$ & $128[71.3-223.5]$ \\
\hline Leukocytes count $\left(/ \mathrm{mm}^{3}\right)$ & $12,600[9330-19,300]$ \\
\hline Creatininemia & $92[56-165]$ \\
\hline
\end{tabular}

Among the 74 patients, $13(17.6 \%)$ were treated with a combination therapy, including an aminoglycoside or a fluoroquinolone in $10(13.5 \%)$ and three $(4.1 \%)$ cases (Table 3$)$, respectively. In $32(43.2 \%)$ cases, first-line antibiotic therapy was switched to another $\beta$ lactam with an average time of 2.2 days. Among them, 19 (59.4\%) were switched before day 3 after initiating antibiotic therapy, and $13(40.6 \%)$ were switched after day 3.

The second line therapy evaluated at day 3 after initiation of first-line antibiotic treatment included cefepime $(41.9 \%)$, piperacillin \pm tazobactam $(23.0 \%), 3 \mathrm{GC}(18.9 \%)$, carbapenem $(5.4 \%)$, sulfamethoxazole-trimethoprim $(4.1 \%)$, fluroquinolone $(2.7 \%)$ and amoxicillin-clavulanate $(1.4 \%)$, and therapies were unknown in $2.1 \%$ of cases. 
Table 2. Antibiotic treatment.

\begin{tabular}{|c|c|c|c|c|c|c|c|c|c|c|c|c|c|c|c|c|c|c|c|c|c|}
\hline \multicolumn{2}{|c|}{ First-Line Treatment } & \multicolumn{2}{|c|}{ Combination with Aminoglycoside } & \multicolumn{2}{|c|}{ Combination with Fluoroquinolone } & \multicolumn{8}{|c|}{ Treatment at $72 \mathrm{~h}$} & \multicolumn{8}{|c|}{$\begin{array}{l}\text { Definitive Treatment } \\
\end{array}$} \\
\hline & $\begin{array}{c}\text { Duration } \\
\text { (Days Mean) }\end{array}$ & $\begin{array}{l}\text { No. (\%) of } \\
\text { Patients }\end{array}$ & $\begin{array}{c}\text { Duration (Days } \\
\text { Mean) }\end{array}$ & $\begin{array}{l}\text { No. (\%) of } \\
\text { Patients }\end{array}$ & $\begin{array}{l}\text { Duration (Days } \\
\text { Mean) }\end{array}$ & $3 \mathrm{GC}$ & Fep & $\mathrm{P} \pm \mathrm{TZ}$ & $\begin{array}{l}\text { No. of } \\
\text { Carb }\end{array}$ & $\begin{array}{l}{ }^{n+s} \\
\mathrm{FQ}\end{array}$ & sXT & AMC & Unknown & $3 \mathrm{GC}$ & Fep & $\mathbf{P} \pm \mathrm{TZ}$ & $\begin{array}{l}\text { No. of Pati } \\
\text { Carb }\end{array}$ & ${ }_{\mathrm{FQ}}$ & SXT & AMC & Unknown \\
\hline $\begin{array}{l}\text { Cefotaxime or } \\
\text { ceftriaxone }\end{array}$ & 5 & $\begin{array}{c}2 \\
(7.7)\end{array}$ & 1 & & 0 & 12 & 8 & 1 & 0 & 2 & 1 & 1 & 1 & 8 & 6 & 0 & 1 & 7 & 2 & 1 & 1 \\
\hline $\begin{array}{c}\text { Piperacilin } \pm \\
\text { tazobactam } \\
\mathrm{N}=23\end{array}$ & 4.6 & $\begin{array}{c}5 \\
(21.8)\end{array}$ & 1.8 & $\begin{array}{c}2 \\
(8.7)\end{array}$ & 14 & 2 & $4^{*}$ & 15 & 1 & 0 & 0 & 0 & 1 & 3 & 4 & 11 & 1 & 1 & 1 & 0 & 2 \\
\hline $\begin{array}{l}\text { Carbapenem } \\
N=4\end{array}$ & 12.5 & $\begin{array}{l}2 \\
(50)\end{array}$ & 2 & & 0 & 0 & 1 & 0 & 3 & 0 & 0 & 0 & 0 & 0 & 0 & 0 & 4 & 0 & 0 & 0 & 0 \\
\hline $\begin{array}{c}\mathrm{N}=4 \\
\text { Total } \\
\mathrm{N}=74 \\
\end{array}$ & 5.8 & $\begin{array}{r}100 \\
10 \\
(13.5) \\
\end{array}$ & 1.5 & $\begin{array}{c}3 \\
(4.1) \\
\end{array}$ & 14 & $\begin{array}{c}14 \\
(18.9)\end{array}$ & $\begin{array}{l}31 \\
(41.9)\end{array}$ & $\begin{array}{l}17 \\
(23.0)\end{array}$ & $\begin{array}{c}4 \\
(5.4)\end{array}$ & $\begin{array}{r}2 \\
(2.7\end{array}$ & $\begin{array}{r}3 \\
(4.1) \\
\end{array}$ & $\begin{array}{c}1 \\
(1.4)\end{array}$ & $\begin{array}{c}2 \\
(2.7)\end{array}$ & $\begin{array}{l}14 \\
(29.9)\end{array}$ & $\begin{array}{r}24 \\
(32.4) \\
\end{array}$ & $\begin{array}{c}12 \\
(16.2)\end{array}$ & $7(9.5)$ & $\begin{array}{c}9 \\
(12.2)\end{array}$ & $\begin{array}{c}4 \\
(5.4)\end{array}$ & $\begin{array}{c}1 \\
(1.4)\end{array}$ & $\begin{array}{c}3 \\
(4.1) \\
\end{array}$ \\
\hline
\end{tabular}

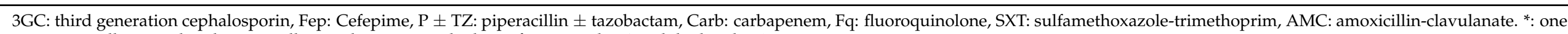
patient initially treated with piperacillin-tazobactam switched to cefepime at day 1 and died at day 2. 
Table 3. Characteristics of patients treated with 3GC.

\begin{tabular}{|c|c|c|c|}
\hline & $\begin{array}{c}\text { 3GC } \\
\text { No. }(\%)\end{array}$ & $\begin{array}{c}\text { Non 3GC } \\
\text { No. }(\%)\end{array}$ & $p$ Value \\
\hline Total & $26(100)$ & $48(100)$ & \\
\hline Male & $22(84.6)$ & $31(64.6)$ & 0.10 \\
\hline Age & $70[57.8-76.3]$ & $67[62.0-78.5]$ & 0.8 \\
\hline $\begin{array}{l}\text { Ward at the time of infection } \\
\text { Medicine } \\
\text { Surgery } \\
\text { ICU } \\
\text { Home }\end{array}$ & $\begin{array}{c}17(65.4) \\
3(11.5) \\
5(19.2) \\
1(3.8)\end{array}$ & $\begin{array}{c}19(39.6) \\
3(6.2) \\
26(54.2) \\
0(0)\end{array}$ & $\begin{array}{c}0.5 \\
0.65 \\
<0.01 \\
0.35\end{array}$ \\
\hline Antibiotic therapy in the last 3 months & $6(23.1)$ & $33(69)$ & $<0.01$ \\
\hline $\begin{array}{l}\text { Underlying disease } \\
\text { Diabetes mellitus } \\
\text { Chronic cardiac disease } \\
\text { Chronic respiratory diseases } \\
\text { Renal insufficiency } \\
\text { Neutropenia } \\
\text { Immunosuppressive treatment } \\
\text { Corticosteroid use } \\
\text { Hematologic malignancies } \\
\text { Solid cancer }\end{array}$ & $\begin{array}{c}5(19.2) \\
9(34.6) \\
2(7.7) \\
4(15.4) \\
0 \\
0 \\
0 \\
1(42.3) \\
12(46.1)\end{array}$ & $\begin{array}{l}13(27.1) \\
5(10.4) \\
12(25.0) \\
6(12.5) \\
0 \\
9(18.8) \\
2(4.2) \\
1(2.1) \\
20(41.2)\end{array}$ & $\begin{array}{l}0.57 \\
0.02 \\
0.11 \\
0.73 \\
\text { NA } \\
0.02 \\
0.53 \\
1 \\
0.8\end{array}$ \\
\hline Charlson score (median, [IQR]) & $2[1-3]$ & $2[1-5]$ & 1 \\
\hline Pitt Score (median, [IQR]) & $2[1-3.25]$ & $4[2-6.25]$ & $<0.01$ \\
\hline $\begin{array}{l}\text { Site of infection } \\
\text { Respiratory tract } \\
\text { Urinary tract } \\
\text { Catheter related } \\
\text { Intra-abdominal } \\
\text { Primary BSI }\end{array}$ & $\begin{array}{c}3(11.5) \\
10(38.5) \\
4(15.4) \\
7(26.9) \\
2(7.7)\end{array}$ & $\begin{array}{l}21(43.8) \\
6(12.5) \\
7(14.6) \\
9(18.8) \\
5(10.4)\end{array}$ & $\begin{array}{c}\text { NA } \\
0.02 \\
0.53 \\
1 \\
0.8\end{array}$ \\
\hline
\end{tabular}

Definitive therapy included cefepime (32.4\%), 3GC (18.9\%), piperacillin \pm tazobactam $(16.2 \%)$, fluroquinolone $(12.2 \%)$, carbapenem $(9.5 \%)$, sulfamethoxazole-trimethoprim $(5.4 \%)$ and amoxicillin-clavulanate $(1.4 \%)$, and therapies were unknown in $4.1 \%$ of cases.

\subsubsection{Third Generation Cephalosporin Therapy}

3GCs were initiated as first-line therapy for $26(35.1 \%)$ patients with a mean duration of treatment of $5( \pm 4.5)$ days. Characteristics of patients in 3GC therapy and characteristics of infections are described Table 3.

According to univariate analysis, 3GC therapy was associated with non-ICU hospitalization ( $54.2 \%$ vs. $3.8 \%$; $p<0.01)$, absence of previous antibiotic therapy in the last 3 months (69.0\% vs. $23.1 ; p<0.01)$, absence of immunosuppressive treatment $(18.8 \%$ vs. $0 \% ; p=0.02)$, lower Pitt score ( 2 vs. $4 ; p<0.01)$, chronic cardiac disease $(34.6 \%$ vs. $10.4 \% ; p=0.02)$ and urinary tract infection $(38.5 \%$ vs. $12.5 \% ; p=0.02)$.

\subsubsection{First Antibiotic Therapy, Clinical Failure and Emergence of Resistance}

Patient outcomes are described in Table 4. Biological and clinical improvements were observed in $70.4 \%$ and $88.6 \%$ of cases, respectively. For all patients we observed a microbiological eradication defined by the reduction of the initially positive microbiological sample (majority of blood cultures).

Four $(5 \%)$ cases of emergence of 3GC resistance were observed during therapy. Characteristics of infections with emergence of 3GC resistance are described in Table 5. All the four patients with 3GC-resistant isolates were hospitalized in the ICU, and three out of four $(75 \%)$ had a pulmonary infection. None of these patients received combination therapy. 
Table 4. Outcome according to initial antibiotic treatment.

\begin{tabular}{|c|c|c|c|c|c|c|c|c|}
\hline & \multicolumn{2}{|l|}{$3 G C$} & \multicolumn{2}{|c|}{ Cefepime } & \multicolumn{2}{|c|}{ Piperacillin \pm Tazobactam } & \multicolumn{2}{|c|}{ Carbapenem } \\
\hline & $\begin{array}{l}\text { No. of Patients } \\
\text { from Available } \\
\text { Data }(\%)\end{array}$ & $p$ Value & $\begin{array}{l}\text { No. of Patients } \\
\text { from Available } \\
\text { Data (\%) }\end{array}$ & $p$ Value & $\begin{array}{c}\text { No. of Patients } \\
\text { from Available } \\
\text { Data }(\%)\end{array}$ & $p$ Value & $\begin{array}{l}\text { No. of Patients } \\
\text { from Available } \\
\text { Data (\%) }\end{array}$ & $p$ Value \\
\hline Clinical improvement & $23 / 25(92)$ & 0.53 & $20 / 20(100)$ & 1.00 & $17 / 22(77)$ & 0.08 & $2 / 3(67)$ & 1.00 \\
\hline Biological improvement & $13 / 21(62)$ & 0.36 & $12 / 14(86)$ & 0.30 & $11 / 17(65)$ & 0.54 & $2 / 2(100)$ & 1.00 \\
\hline Emergence of 3GC resistance during treatment & $1 / 26(4)$ & 1.00 & $0 / 21(0)$ & 0.55 & $3 / 23(13)$ & 0.08 & $0 / 0(0)$ & 1.00 \\
\hline
\end{tabular}

Table 5. Characteristics of infections with emergence of resistance.

\begin{tabular}{|c|c|c|c|c|c|c|c|c|c|c|c|c|c|c|c|}
\hline \multirow[b]{2}{*}{ Patient } & \multirow[b]{2}{*}{ Sex } & \multirow{2}{*}{$\begin{array}{l}\text { Age } \\
\text { (Years) }\end{array}$} & \multirow{2}{*}{$\begin{array}{l}\text { Weight } \\
\text { (Kg) }\end{array}$} & \multirow{2}{*}{ Ward } & \multirow{2}{*}{ Charlson } & \multirow{2}{*}{$\begin{array}{l}\text { Sofa } \\
\text { Score }\end{array}$} & \multirow{2}{*}{$\begin{array}{l}\text { Creatinine } \\
\text { Clearance } \\
\text { (mL/min) }\end{array}$} & \multirow{2}{*}{$\begin{array}{l}\text { Source of } \\
\text { Infection }\end{array}$} & \multicolumn{3}{|c|}{ Treatment 1} & \multicolumn{3}{|c|}{ Treatment 2} & \multirow{2}{*}{$\begin{array}{l}\text { Day of Emergence of } \\
\text { Resistance (Site of } \\
\text { Isolation) }\end{array}$} \\
\hline & & & & & & & & & Antibiotic & $\begin{array}{l}\text { Dosage } \\
\text { g/24h }\end{array}$ & $\begin{array}{c}\text { Duration } \\
\text { (Days) }\end{array}$ & Antibiotic & $\begin{array}{l}\text { Dosage } \\
\text { g/24 h }\end{array}$ & $\begin{array}{c}\text { Duration } \\
\text { (Days) }\end{array}$ & \\
\hline 1 & $\mathrm{M}$ & 31 & 41 & ICU & 8 & 2 & 64 & Pulmonary & $3 G C$ & 3 & 2 & AMC & Un & 3 & 5 (pulmonary) \\
\hline 2 & $\mathrm{M}$ & 64 & 109 & ICU & 2 & 7 & 136 & Pulmonary & $\begin{array}{l}\text { Piperacillin } \\
\text { tazobactam }\end{array}$ & 12 & 3 & No & NA & NA & 3 (pulmonary) \\
\hline 3 & $\mathrm{~F}$ & 21 & 56 & ICU & 1 & 7 & 155 & Catheter & $\begin{array}{l}\text { Piperacillin } \\
\text { tazobactam }\end{array}$ & 12 & 3 & No & NA & NA & 3 (bloodstream) \\
\hline
\end{tabular}


According to univariate analysis, piperacillin \pm tazobactam as first-line therapy was the only variable associated with a lower clinical improvement and a higher risk of emergence of resistance, but the difference was not statistically significant $(77 \%$ vs. $94 \% p=0.08$ and $13 \%$ vs. $2 \% p=0.08$, respectively). As shown by the univariate analysis, no factor was associated with better biological improvement. Among our population, overall 30-day mortality was $14 \%$, and treatment with 3GC as first-line therapy was the only variable associated with a lower mortality (not statistically significant; $4 \%$ vs. $19 \% ; p=0.08$ ).

\section{Discussion}

In the present prospective observational study, we found that 3GC therapy used as first-line therapy to treat pulmonary and/or BSI related to Enterobacter spp. was not associated with clinical failure and emergence of resistance. Moreover, we found a low rate of emergence of resistance during therapy with only four cases $(5 \%)$ in our cohort, and this emergence of resistance was not associated with clinical failure.

Several studies reported the risk of emergence of resistance during 3GC therapy, but none of them examined the clinical impact of this phenomenon as primary objective. Nevertheless, overall mortality was examined, but 3GC therapy or emergence of resistance during therapy was not associated with a higher mortality. A landmark prospective observational study underlined a high risk of emergence of resistance for $\mathrm{AE}$ infection treated with 3GC, but this was not associated with 14 days mortality $(4 / 3113 \%$ vs. $15 / 87$ $17 \% ; p>0.2$ ] [3]. Similarly, in a prospective study including $732 \mathrm{AE}$ infections, 218 patients received 3GC therapy, and Choï et al. found that emergence of resistance during 3GC therapy was not associated with mortality $(1 / 119.1 \%$ vs. $2 / 2071.0 \% ; p=0.144)$ [5]. In our study, 3GC was the most common antibiotic prescribed as initial therapy and, as previously described, was not associated with a higher mortality, but several confounding factors were not included in the analysis such as initial gravity, co-morbidities and site of infection. Interestingly, 3GC therapy was associated with a lower Pitt score and non-ICU patients (Table 3) suggesting that we can safely use 3GC therapy for non-severe patients. Half 3GC initial therapies were switched for another $\beta$-lactamin such as cefepime, while clinical improvement was observed in $92 \%$ of cases. Furthermore, in this study, none of the empirical treatments active against Enterobacter spp. were associated with better outcome as previously described [13]. Therefore, we can question the necessity of switching treatment for patients with a clinical improvement $72 \mathrm{~h}$ after 3GC therapy.

Previous old studies [3,4] reported an emergence of resistance rate of $19 \%$ with several unreported limitations. In a more recent study, Choï et al. found an overall incidence for $3 \mathrm{GC}$ resistance during therapy of $5.0 \%$, and among AE, Enterobacter spp. have the highest risk of emergence of 3GC resistance during therapy with $8.3 \%$. In our study, we also found a low rate of emergence of resistance during therapy with only four cases (5\%). Surprisingly, emergence of resistance occurred more frequently for patients treated with piperacillin \pm tazobactam, but the difference, due to a low number of events, was not statistically significant. A previous exposure to piperacillin \pm tazobactam has been reported to be a risk factor for isolating broad spectrum cephalosporin resistant Enterobacter spp. [14] but not emergence of 3GC resistance during therapy.

We cannot consider the impact of tazobactam as an inducer in emergence of the $3 \mathrm{GC}$ resistance phenomenon. Firstly, tazobactam is only a weak inducer of AmpC beta-lactamase, in comparison to clavulanate [15]. Secondly, emergence of 3GC resistance is due to the selection of a constitutive 3GC resistant mutant among a susceptible population and not to antibiotic induction, a temporary in vitro phenomenon [16]. This emergence seems theoretically more frequent when piperacillin is used compared to 3GC in our study. This could be explained by the high basal MIC of Enterobacter spp. for piperacillin $(1 \mu \mathrm{g} / \mathrm{mL}$ compared to $0.03 \mu \mathrm{g} / \mathrm{mL}$ cefotaxime and cefepime) [17]. Epidemiological cut-off values (ECOFFs) for Enterobacter cloacae reported by EUCAST are $8.0 \mu \mathrm{g} / \mathrm{mL}$ for piperacillin \pm tazobactam, $0.5 \mu \mathrm{g} / \mathrm{mL}$ for cefotaxime and $0.125 \mu \mathrm{g} / \mathrm{mL}$ for cefepime. Therefore, our results suggest that piperacillin \pm tazobactam should be prescribed cautiously for Enterobacter spp. infec- 
tions especially as we found the lowest clinical improvement with this treatment. Several studies have already warned of the necessity to optimize the administration and use a high dosage of piperacillin-tazobactam in order to reach pharmacological targets for ICU or severe-sepsis patients $[18,19]$.

Emergence of 3GC resistance during therapy for AE infections has always been associated with the use of 3GC $[3-5,20,21]$. To our knowledge, this is the first prospective multi-centric study including infections due to Enterobacter spp. only susceptible to 3GC. Emergence of 3GC resistance is due to the selection of a constitutive 3GC resistant mutant among a susceptible population. We found that this is a rare event, and the choice of the molecule is not the key issue; other factors such as the initial severity, MIC, dosage, the inoculum size and the source of infection should be taken into consideration as Choi et al. suggested.

One of the main limitations of our study is the small sample size of our cohort, as in others $[3,20,21]$. This is because we included only deep infections such as pulmonary and bloodstream infections and only strains susceptible to 3GC. We could not generalize our results for different infection sites because of the sample size; only univariate analysis could be performed. Moreover, our study was observational but not randomized.

\section{Conclusions}

Clinical failure related to emergence of 3GC resistant AE by AmpC overproduction is still a debated issue. In this prospective multicentric observational study, we found that 3GC therapy can be safely used as first-line therapy especially for non-severe patients suffering from pulmonary or bloodstream infections due to Enterobacter spp. Emergence of $3 \mathrm{GC}$ resistance remains a rare event, and there is a lack of evidence of the benefit of last-line antibiotics therapies.

Author Contributions: Conceptualization: B.P., T.D. and J.-R.Z.; Methodology: T.D., A.M. and J.-R.Z.; Investigation: A.B. (Anna Belkacem), P.C.-P., S.K., S.A., E.C. (Etienne Canoui) and A.B. (Alexandre Bleibtreu); Formal analysis: B.P., T.D. and S.K.; Writing—original draft preparation: B.P. and T.D.; Writing-review: M.L., S.K., E.C. (Etienne Carbonelle) and J.-R.Z. All authors have read and agreed to the published version of the manuscript.

Funding: This research received no external funding.

Institutional Review Board Statement: The study was conducted according to the guidelines of the Declaration of Helsinki, and approved by the Institutional Review Board of Avicenne Hospital (IRB number CLEA 2020-180).

Informed Consent Statement: Informed consent was obtained from all subjects involved in the study.

Conflicts of Interest: The authors declare no conflict of interest.

\section{References}

1. Jacoby, G.A. AmpC beta-lactamases. Clin. Microbiol. Rev. 2009, 22, 161-182. [CrossRef] [PubMed]

2. Livermore, D.M.; Brown, D.F.; Quinn, J.P.; Carmeli, Y.; Paterson, D.L.; Yu, V.L. Should third-generation cephalosporins be avoided against AmpC-inducible Enterobacteriaceae? Clin. Microbiol. Infect. 2004, 10, 84-85. [CrossRef] [PubMed]

3. Chow, J.W.; Fine, M.J.; Shlaes, D.M.; Quinn, J.P.; Hooper, D.C.; Johnson, M.P.; Ramphal, R.; Wagener, M.M.; Miyashiro, D.K.; Yu, V.L. Enterobacter bacteremia: Clinical features and emergence of antibiotic resistance during therapy. Ann. Intern. Med. 1991, 115, 585-590. [CrossRef] [PubMed]

4. Kaye, K.S.; Cosgrove, S.; Harris, A.; Eliopoulos, G.M.; Carmeli, Y. Risk factors for emergence of resistance to broad-spectrum cephalosporins among Enterobacter spp. Antimicrob. Agents Chemother. 2001, 45, 2628-2630. [CrossRef] [PubMed]

5. Choi, S.H.; Lee, J.E.; Park, S.J.; Choi, S.H.; Lee, S.O.; Jeong, J.Y.; Kim, M.N.; Woo, J.H.; Kim, Y.S. Emergence of antibiotic resistance during therapy for infections caused by Enterobacteriaceae producing AmpC beta-lactamase: Implications for antibiotic use. Antimicrob. Agents Chemother. 2008, 52, 995-1000. [CrossRef] [PubMed]

6. Sader, H.S.; Farrell, D.J.; Flamm, R.K.; Jones, R.N. Antimicrobial susceptibility of Gram-negative organisms isolated from patients hospitalised with pneumonia in US and European hospitals: Results from the SENTRY Antimicrobial Surveillance Program, 2009-2012. Int. J. Antimicrob. Agents 2014, 43, 328-334. [CrossRef] [PubMed]

7. Harris, P.N.; Ferguson, J.K. Antibiotic therapy for inducible AmpC $\beta$-lactamase-producing Gram-negative bacilli: What are the alternatives to carbapenems, quinolones and aminoglycosides? Int. J. Antimicrob. Agents 2012, 40, 297-305. [CrossRef] [PubMed] 
8. Moy, S.; Sharma, R. Treatment Outcomes in Infections Caused by "SPICE" (Serratia, Pseudomonas, Indole-positive Proteus, Citrobacter, and Enterobacter) Organisms: Carbapenem versus Noncarbapenem Regimens. Clin. Ther. 2017, 39, 170-176. [CrossRef] [PubMed]

9. Charlson, M.E.; Pompei, P.; Ales, K.L.; MacKenzie, C.R. A new method of classifying prognostic comorbidity in longitudinal studies: Development and validation. J. Chronic Dis. 1987, 40, 373-383. [CrossRef]

10. Bone, R.C.; Sprung, C.L.; Sibbald, W.J. Definitions for sepsis and organ failure. Crit. Care Med. 1992, 20, 724-726. [CrossRef] [PubMed]

11. Horan, T.C.; Andrus, M.; Dudeck, M.A. CDC/NHSN surveillance definition of health care-associated infection and criteria for specific types of infections in the acute care setting. Am. J. Infect. Control 2008, 36, 309-332. [CrossRef] [PubMed]

12. EUCAST: Clinical Breakpoints and Dosing of Antibiotics. Available online: http://www.eucast.org/clinical_breakpoints/ (accessed on 10 April 2021).

13. Chaubey, V.P.; Pitout, J.D.; Dalton, B.; Gregson, D.B.; Ross, T.; Laupland, K.B. Clinical and microbiological characteristics of bloodstream infections due to AmpC $\beta$-lactamase producing Enterobacteriaceae: An active surveillance cohort in a large centralized Canadian region. BMC Infect. Dis. 2014, 14, 647. [CrossRef] [PubMed]

14. Schwaber, M.J.; Graham, C.S.; Sands, B.E.; Gold, H.S.; Carmeli, Y. Treatment with a broad-spectrum cephalosporin versus piperacillin-tazobactam and the risk for isolation of broad-spectrum cephalosporin-resistant Enterobacter species. Antimicrob. Agents Chemother. 2003, 47, 1882-1886. [CrossRef] [PubMed]

15. Akova, M.; Yang, Y.; Livermore, D.M. Interactions of tazobactam and clavulanate with inducibly-and constitutively-expressed Class I beta-lactamases. J. Antimicrob. Chemother. 1990, 25, 199-208. [CrossRef] [PubMed]

16. Goldstein, F.W. Cephalosporinase induction and cephalosporin resistance: A longstanding misinterpretation. Clin. Microbiol. Infect. 2002, 8, 823-825. [CrossRef] [PubMed]

17. Livermore, D.M. beta-Lactamases in laboratory and clinical resistance. Clin. Microbiol. Rev. 1995, 8, 557-584. [CrossRef] [PubMed]

18. Pilmis, B.; Jullien, V.; Tabah, A.; Zahar, J.R.; Brun-Buisson, C. Piperacillin-tazobactam as alternative to carbapenems for ICU patients. Ann. Intensive Care 2017, 7, 113. [CrossRef] [PubMed]

19. Dulhunty, J.M.; Roberts, J.A.; Davis, J.S.; Webb, S.A.; Bellomo, R.; Gomersall, C.; Shirwadkar, C.; Eastwood, G.M.; Myburgh, J.; Paterson, D.L.; et al. Continuous infusion of beta-lactam antibiotics in severe sepsis: A multicenter double-blind, randomized controlled trial. Clin. Infect. Dis. 2013, 56, 236-244. [CrossRef] [PubMed]

20. Füssle, R.; Biscoping, J.; Behr, R.; Sziegoleit, A. Development of resistance by Enterobacter cloacae during therapy of pulmonary infections in intensive care patients. Clin. Investig. 1994, 72, 1015-1019. [CrossRef] [PubMed]

21. Kang, C.I.; Kim, S.H.; Park, W.B.; Lee, K.D.; Kim, H.B.; Oh, M.D.; Kim, E.C.; Choe, K.W. Bloodstream infections caused by Enterobacter species: Predictors of 30-day mortality rate and impact of broad-spectrum cephalosporin resistance on outcome. Clin. Infect. Dis. 2004, 39, 812-818. [CrossRef] [PubMed] 